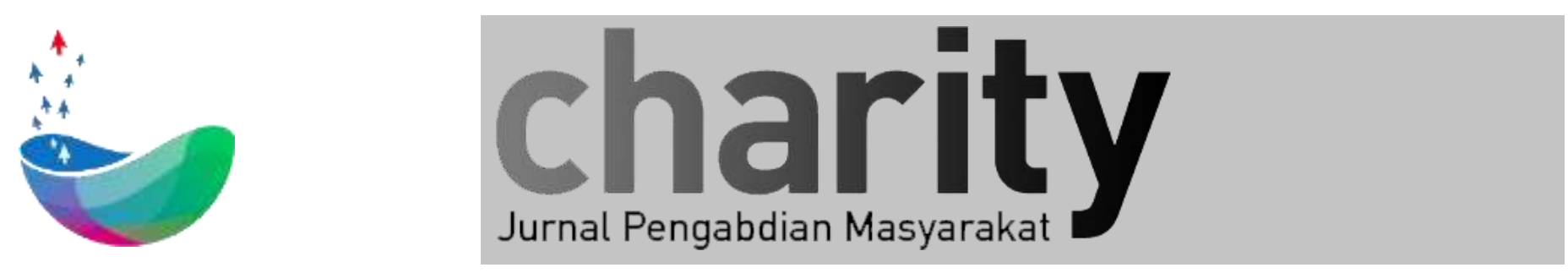

\title{
PELATIHAN KEMASAN PRODUK KULINER YANG PERSUASIF BAGI KOPERASI DAN UKM KABUPATEN BANDUNG
}

\author{
Wirania Swasty ${ }^{*}$, Yanuar Rahman ${ }^{2}$, Atria N. Fadilla ${ }^{3}$ \\ $1,2,3$ Dept. Desain Komunikasi Visual, Fakultas Industri Kreatif, Universitas Telkom \\ *wirania@telkomuniversity.ac.id
}

\section{INFO ARTIKEL}

Diterima 26 Juni 2019

Direvisi 03 Juli 2019

Disetujui 30 Agustus 2019

Tersedia Online 09 September 2019

\begin{abstract}
ABSTRAK
Kemasan dapat mempengaruhi pembeli dalam memilih dan membeli suatu produk. Namun fakta di lapangan, banyak pelaku Usaha Kecil dan Menengah (UKM) khususnya di Kabupaten Bandung masih belum memahami pentingnya kemasan yang persuasif yang menjual. Solusi yang ingin dicapai melalui program pengabdian masyarakat ini salah satunya adalah melatih kreativitas membuat label kemasan yang persuasif yang dapat membujuk konsumen untuk membeli produk. Bentuk kegiatan pengabdian masyarakat ini berupa pelatihan desain kemasan yang persuasif bagi pelaku UKM dan koperasi Kabupaten Bandung. Adapun manfaatnya adalah agar mereka mengetahui pentingnya kemasan dalam mempengaruhi pembeli dalam memilih dan membeli suatu produk di samping menjaga higienitas produk. Program pengabdian masyarakat kali ini bekerjasama dengan Dinas Koperasi UKM Kabupaten Bandung sebagai mitra program. Peran Dinas Koperasi UKM Kabupaten Bandung pada program ini sebagai fasilitator yang mengundang peserta berupa pelaku Usaha Kecil dan Menengah (UKM) di lingkungan Kabupaten Bandung. Adapun jumlah peserta pelatihan sebanyak 35 partisipan. Program ini dilaksanakan mulai dari Bulan April hingga Agustus 2018
\end{abstract}

Keyword: Desain, Kemasan, Persuasif, Koperasi, UKM

Korespondensi:

Direktorat Penelitian dan Pengabdian Masyarakat, Universitas Telkom

Jl. Telekomunikasi No. 1, Terusan Buah Batu, Bandung, 40257 Indonesia.

E-mail: charity@telkomuniversity.ac.id

ORCID ID: 0000-0001-6586-2697

Penulis Pertama: Wirania Swasty

https://doi.org/10.25124/charity.v2i1.2067

Paper_reg_number 2067 (C) The Authors. Published by Directorate of Research and Community Service, Telkom University.

This is an open access article under the CC BY-NC 4.0 license (https://creativecommons.org/licenses/ by-nc/4.0/) 


\section{Pendahuluan}

Ada banyak spesifikasi teknis yang harus dipenuhi kemasan di antaranya: harus aman, tahan lama, hemat biaya, dan tahan terhadap kerusakan dan lainlain. Lebih dari itu, dibutuhkan keseluruhan desain kemasan yang dapat menjual produk. Referensi [1] menekankan pentingnya fungsi pemasaran dari kemasan dan proses persepsi konsumen dalam pencarian informasi mereka mengenai desain dan label kemasan.

Grafis kemasan merupakan presentasi visual dalam bentuk kombinasi teks, ilustrasi dan warna pada suatu benda yang digunakan untuk tempat/wadah dan dikemas serta dapat memberikan perlindungan bagi produk di dalamnya sesuai dengan tujuanya serta dapat menarik minat konsumen untuk membeli [2].

Program pengabdian masyarakat terdahulu antara lain Redesain Kemasan Produk Kuliner UKM Kabupaten Bandung untuk meingkatkan Nilai Jual, Pelatihan Desain Eco-Packaging Berbahan Kertas/ Karton bagi Wira Usaha Muda di Kecamatan Regol-Bandung, Membangun Brand Awareness dan Keputusan Pembelian Masyarakat akan Hasil Produksi Pertanian Melalui Kemasan, serta Pelatihan Pengemasan Hasil Pertanian untuk Mewujudkan Pembangunan Berwawasan Agribisnis.

Adapun maksud dan tujuan yang ingin dicapai melalui program pengabdian masyarakat kali ini di antaranya: (1) Meningkatkan pengetahuan mengenai struktur dan material kemasan untuk produk kuliner Usaha Kecil dan Menengah; (2) Mengembangkan potensi kreatif pelaku UKM terutama di Kabupaten Bandung dalam memasarkan produknya; (3) Melatih kreatifitas membuat label atau PDP kemasan yang persuasif yang dapat membujuk konsumen untuk membeli produk.

\section{Masalah}

Dari uraian sebelumnya, dapat diambil inti bahwa kemasan merupakan hal yang tak terpisahkan dari produk. Selain melindungi produk pada saat dikirim, disimpan dan dipajang di rak swalayan, kemasan mempunyai arti yang tak kalah penting dalam meningkatkan penjualan. Kemasan dapat mempengaruhi pembeli dalam memilih dan membeli suatu produk.

Namun fakta di lapangan, banyak pelaku Usaha Kecil dan Menengah (UKM) khususnya di Kabupaten Bandung masih belum memahami pentingnya kemasan yang persuasif dan menjual. Berikut adalah beberapa kemasan UKM Kabupaten Bandung khususnya produk kuliner. 

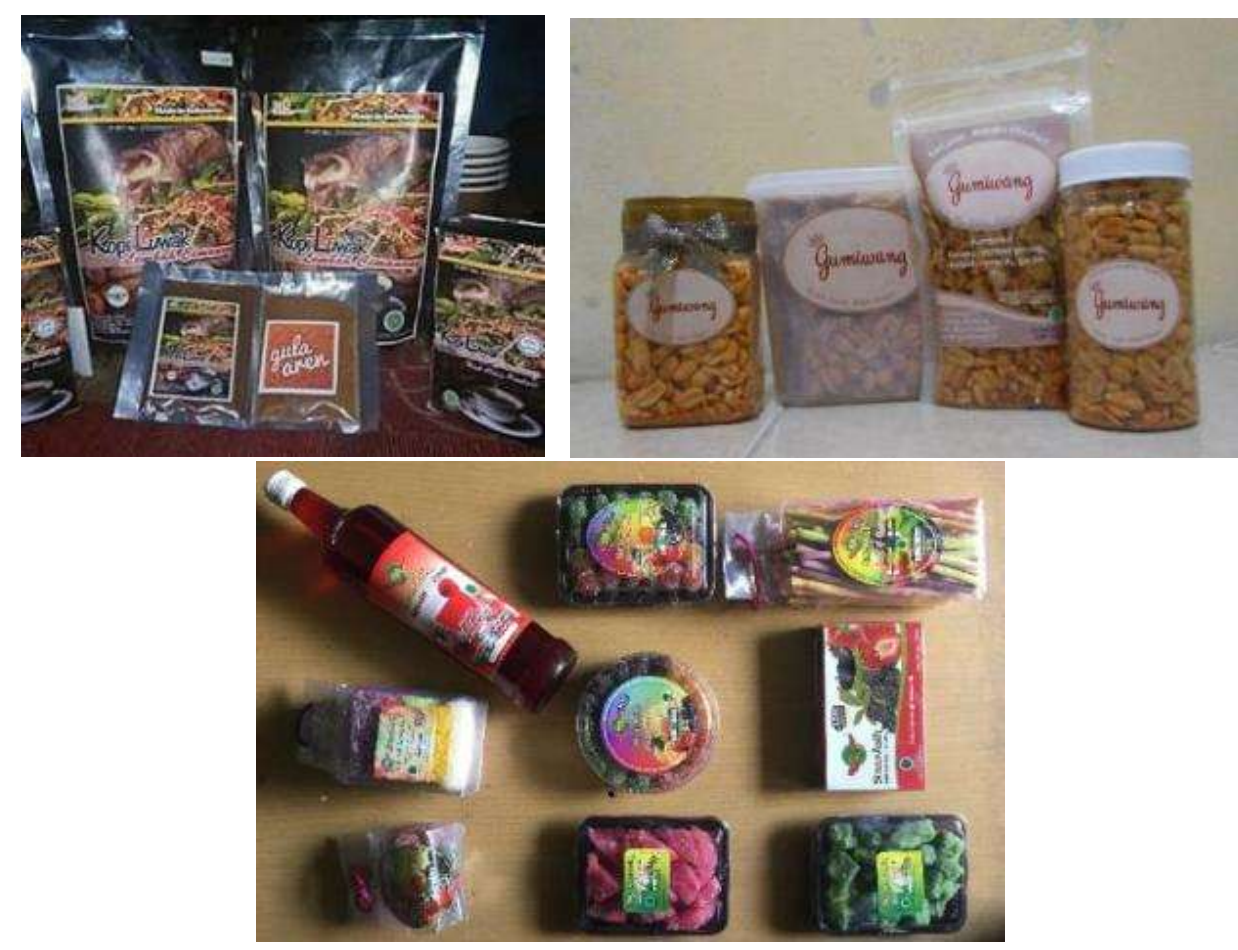

Gambar 1 Kemasan Produk UKM Kabupaten Bandung

Untuk itu, menarik bagi kami tim dosen Desain Komunikasi Visual Universitas Telkom mengangkat topik kemasan yang persuasif dalam program pengabdian masyarakat yang ditujukan bagi kelompok masyarakat yang kurang produktif.

\section{Metode Pelaksanaan}

Bentuk kegiatan pengabdian masyarakat ini berupa pelatihan desain kemasan yang persuasif bagi pelaku UKM dan koperasi Kabupaten Bandung. Adapun manfaatnya adalah agar mereka mengetahui pentingnya kemasan dalam mempengaruhi pembeli dalam memilih dan membeli suatu produk di samping menjaga higienitas produk. Lebih lanjut lagi, selain segi estetis yang ditonjolkan, kemasan yang dirancang juga memperhatikan kesehatan manusia dan kebersihan lingkungan.

Mitra program Pengabdian kepada Masyarakat $(\mathrm{PkM})$ ini adalah Dinas Koperasi UKM Kabupaten Bandung. Dinas Koperasi UKM Kabupaten Bandung sendiri memiliki banyak program dan masyarakat/ usaha binaan. Masyarakat sasar dalam hal ini merupakan Masyarakat Dunia Usaha (kecil, menengah) meliputi usaha rumahan, usaha kecil hingga kepada usaha menengah. Peran Dinas Koperasi UKM Kabupaten Bandung pada program ini sebagai fasilitator yang mengundang peserta berupa pelaku Usaha Kecil dan Menengah (UKM) di lingkungan Kabupaten Bandung. Adapun jumlah peserta pelatihan sejumlah 35 orang.

Program ini mengambil tempat di lantai 4 Gedung Fakultas Industri Kreatif Telkom University pada tanggal 2 Agustus 2018. Kegiatan ini dilakukan selama 1 hari. Sesi pertama adalah pemaparan materi, dilanjutkan workshop/ pelatihan pembuatan kemasan yang persuasif. 
Untuk memahami lebih dalam dan mendapat gambaran mengenai desain kemasan yang telah dimiliki UKM dan Koperasi Kabupaten Bandung, pengumpulan data dilakukan dengan penyebaran kuesioner mengenai desain kemasan (di samping kuesioner mengenai kegiatan program) kepada peserta kegiatan. Adapun pengolahan data dilakukan dengan analisis deskriptif.

\section{Analisa Hasil Kegiatan}

Kegiatan pelatihan ini diikuti oleh 35 peserta dengan usia yang beragam 18 tahun hingga 57 tahun, sebagian besar pesertanya adalah wanita (75\%). Pendidikan terakhir peserta sebagian besar (85\%) adalah Sekolah Menengah Atas (SMA), dengan pekerjaan sebagian besar (82\%) adalah sebagai wirausaha. Sebanyak 15 orang (44\%) peserta memiliki penghasilan Rp 1.400.000 - Rp 2.800.000 atau tergolong dalam Status Ekonomi Sosial (SES) C menurut referensi [3]. 29 peserta (83\%) menjual makanan / minuman namun hanya 20 dari 29 peserta yang sudah memiliki kemasan untuk produknya.

Pada saat kegiatan, peserta diminta untuk mengisi kuesioner seputar kemasan dan produknya. Dari kuesioner, terungkap bahwa 15 peserta mendesain kemasannya sendiri, selebihnya dibantu oleh percetakan atau produsen kemasan. Namun $100 \%$ dari keseluruhan peserta menjawab bahwa diperlukannya pengembangan kemasan yang dilakukan secara profesional yakni oleh desainer grafis dan pakar kemasan dalam hal ini.

Dari kuesioner terungkap bahwa pertimbangan utama dalam pembuatan kemasan adalah desain yang menarik dan berbeda (60\%), diikuti harga produksi $(23 \%)$ dan fungsi dari kemasan itu sendiri (17\%) sebagaimana diilustrasikan pada Gambar 2.

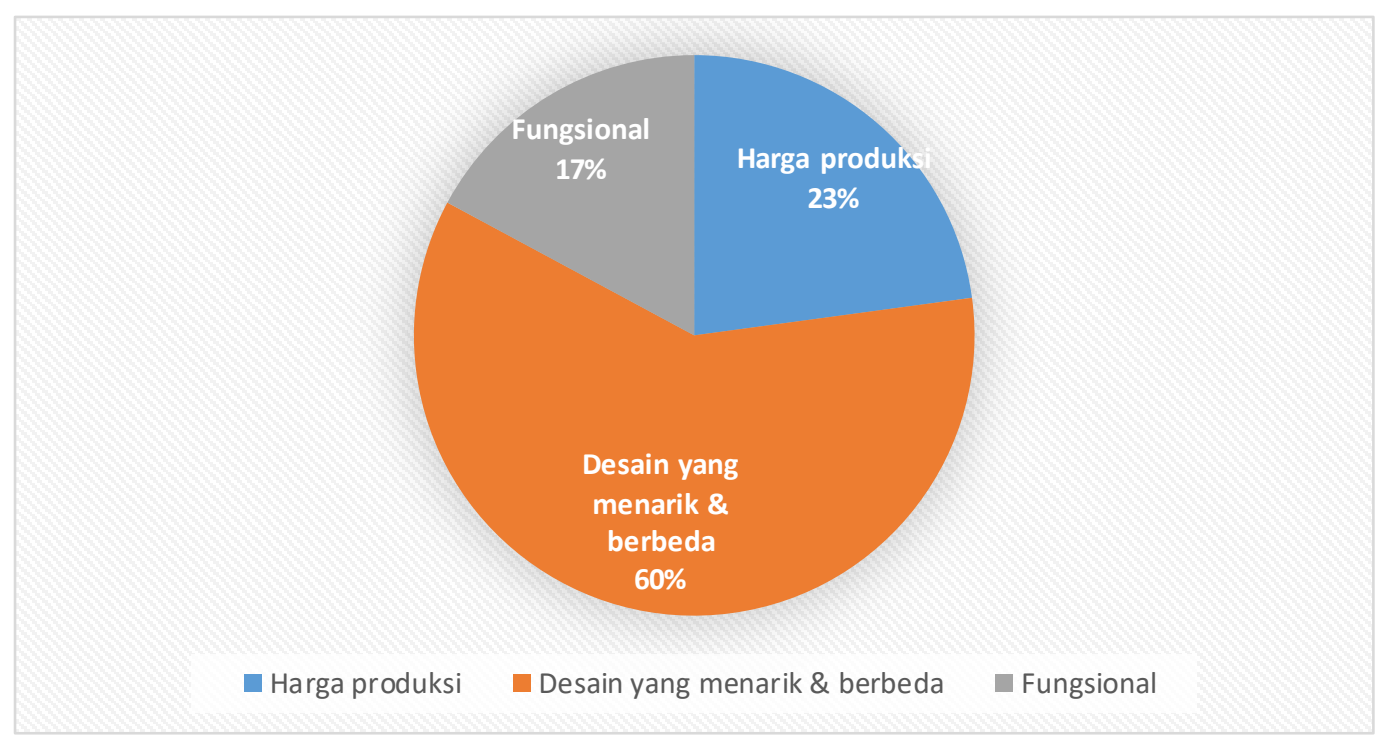

Gambar 2 pertimbangan utama dalam pembuatan kemasan (n: 35) 
Dari kuesioner terungkap bahwa hanya empat peserta yang produknya telah terdapat di retail modern, terutama di Toko Oleh-Oleh Bandung seperti Makuta dan Kunafe. Sebagian besar produk dari UKM tersebut justru belum memasuki retail modern. Adapun alasan belum memasuki retail modern di antaranya terkait masalah biaya, koneksi ke retail modern, perijinan (label halal, nomer P-IRT), belum punya standar kualitas serta produk belum dikemas secara menarik/ desain kemasan masih minim. Untuk itu, program pelatihan ini salah satunya ditujukan untuk melatih kreatifitas membuat label atau Primary Display Panel (PDP) kemasan yang persuasif yang dapat membujuk konsumen untuk membeli produk.

Pertama-tama, peserta diberikan pengetahuan dasar mengenai definisi dan fungsi kemasan. Pengemasan mempunyai dua fungsi, pertama fungsi protektif yakni melindungi produk dari perbedaan iklim, prasarana transportasi, dan saluran distribusi; kedua fungsi promosional yang menyangkut promosi perusahaan, dengan mempertimbangkan preferensi konsumen pada aspek warna, ukuran, dan penampilan [4]. Kemudian, materi dilanjutkan dengan pemaparan mengenai tujuan pengemasan serta bahanbahan yang sering dipakai sebagai bahan dasar kemasan.

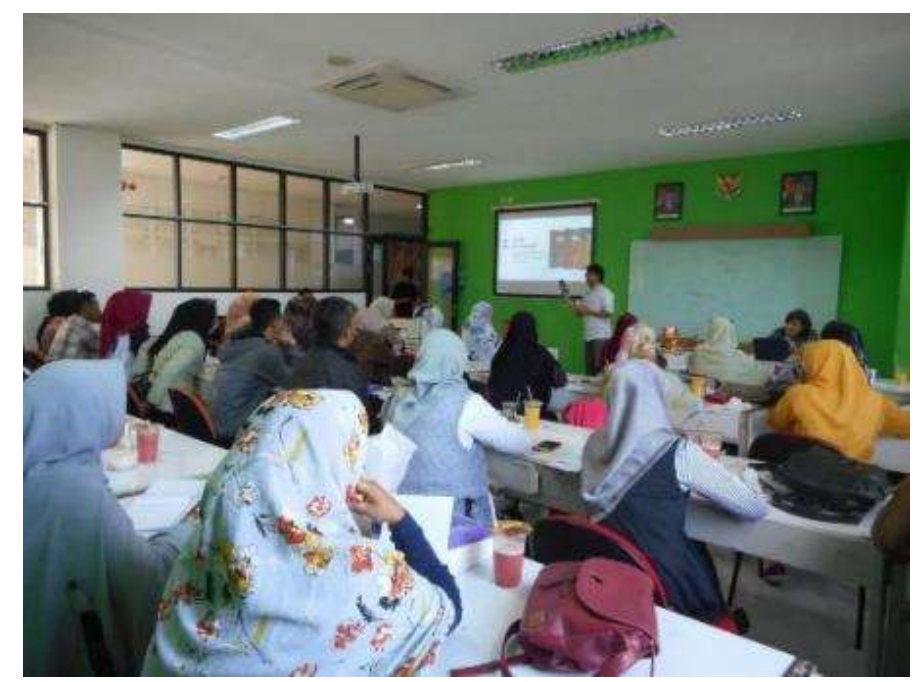

Gambar 3 Suasana ketika pemaparan materi

Setelah itu, peserta diberi pengetahuan mengenai Primary Display Panel (PDP) serta elemen visual maupun verbal apa saja yang harus terdapat pada PDP tersebut. Dalam desain kemasan, PDP merupakan area terpenting dalam aspek komunikasi visual dan strategi pemasaran. Selanjutnya disampaikan materi inti berupa desain kemasan yang persuasif.

Dalam studi BrandSpark International dikemukakan bahwa hanya sepertiga dari konsumen yang tahu pasti merek apa yang akan mereka beli pada kunjungan berikutnya ke toko kelontong/ supermarket. Statistik tersebut menunjukkan pentingnya memenangkan pertempuran di rak pajang. Sebuah kemasan produk adalah kesempatan terakhir seorang pemasar harus 
meyakinkan pembelinya bahwa produknya lebih unggul dan layak dibeli dibandingkan dengan banyak pilihan yang ada di sampingnya. Selama lebih dari 10 tahun Brandspark telah menguji hubungan kemasan dengan konsumen. Database ini dapat memberikan pemahaman mengenai apa yang membuat kemasan menjadi suatu bentuk pemasaran yang persuasif [5].

Terdapat delapan pendekatan kemasan persuasif sebagaimana dijabarkan oleh referensi [5]. Pertama, kemasan harus mampu mengkomunikasikan manfaat produk dan titik diferensiasi merek dalam memenangkan penjualan. Kedua, perlu adanya informasi kepada pembeli bagaimana produk akan membantu dan bermanfaat bagi mereka. Ketiga, desain kemasan (bentuk, warna, fitur pengemasan) harus dapat berkomunikasi secara jelas dan menekankan manfaat produk dan merek. Keempat, kemasan dengan warnawarna cerah cenderung tampil lebih baik daripada penggunaan berwarna kusam.

Kelima, kemasan harus mampu menarik perhatian "target" utama mengingat pembeli di lorong supermarket akan dibombardir oleh beragam kemasan dan segala sesuatu yang dilihat oleh mereka. Pendekatan selanjutnya adalah perlunya menguji kemasan dengan target audiens sebelum melakukan produksi kemasan. Selain itu, pembeli dapat dibujuk untuk membeli produk jika produk yang ada di dalam kemasan terlihat dari luar misalnya dengan menggunakan jendela kecil atau bahan transparan. Hal tersebut dapat membantu meyakinkan pembeli bahwa mereka mendapatkan apa yang mereka bayar. Terakhir, meskipun ini bukan alasan utama, namun akan menjadi nilai lebih jika kemasan dapat dipergunakan kembali setelah produk di dalamnya telah dipakai atau dikonsumsi.

Setelah materi mengenai definisi, fungsi, bahan, Primary Display Panel (PDP) dan prinsip kemasan persuasif dijelaskan, peserta pelatihan kemudian diminta berkreasi membuat Primary Display Panel. Hal ini ditujukan agar mereka mampu memahami apa yang telah dipaparkan dengan langsung mempraktekkan teori yang baru saja didapat. Setiap peserta diberikan karton template kemasan serta gambar untuk ditempel sebagai elemen visual PDP. 

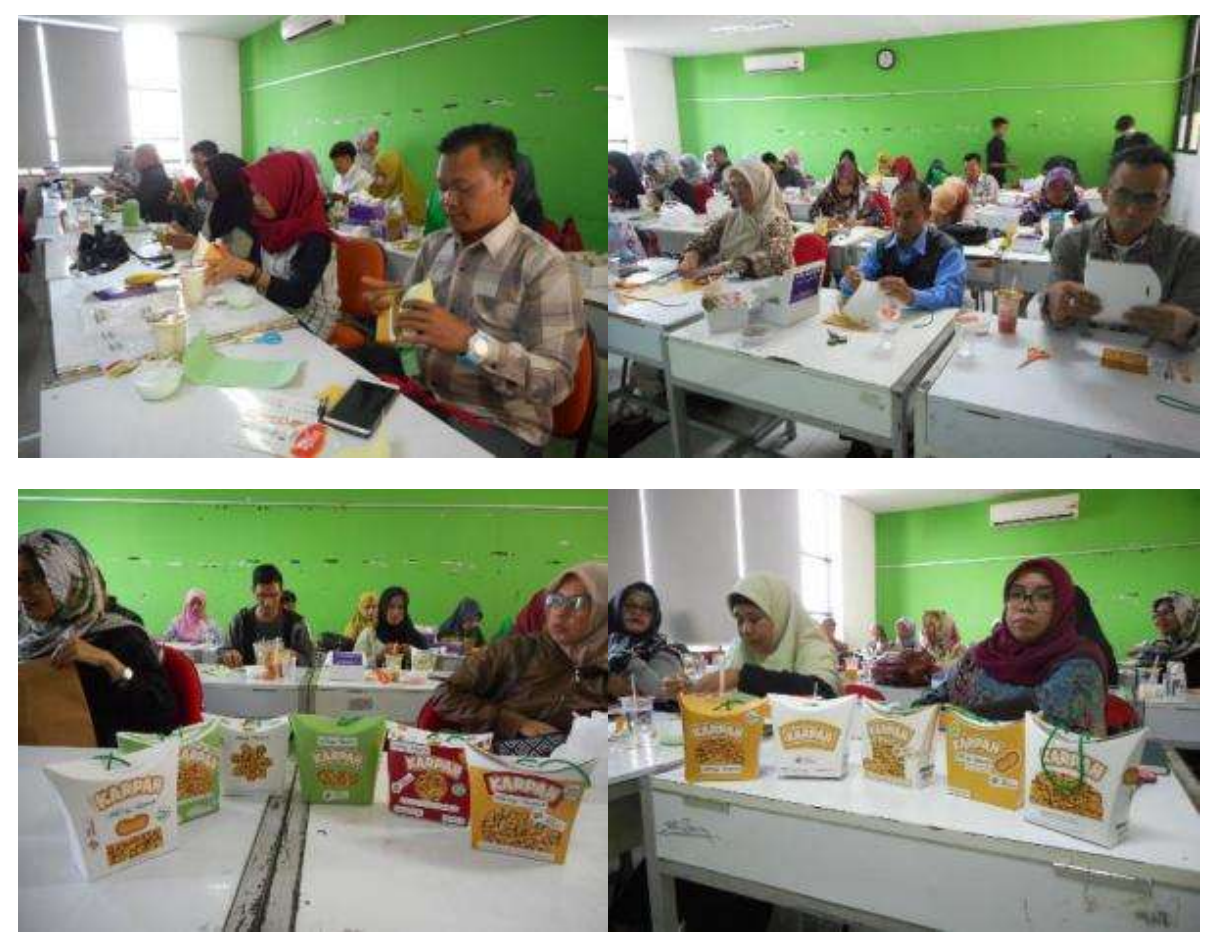

Gambar 4 (atas) Suasana ketika peserta berkreasi membuat kemasan karton dan Primary Display Panel; (bawah) beberapa hasil kreasi terbaik dari peserta pelatihan

Program Pengabdian kepada Masyarakat ini memiliki luaran berupa pelatihan. Jika dilihat kesesuaian dengan kondisi masyarakat dalam hal ini pelaku UKM dan Koperasi Kabupaten Bandung, maka program ini memiliki keunggulan di mana peserta tidak hanya mendapat materi berupa teori saja, namun juga praktek langsung.

\section{Kesimpulan dan Saran}

Ketika acara berlangsung, para peserta dibagikan kuesioner untuk diisi dan ditukarkan dengan sertifikat. Terkumpul 35 lembar kuesioner dari 35 peserta. Berdasarkan masukan dari masyarakat sasar terhadap kegiatan pengabdian kepada masyarakat yang telah dilaksanakan, program Pengabdian kepada Masyarakat (PkM) yang diselenggarakan ini dinilai sangat Baik (Jumlah Setuju dan Sangat Setuju semuanya di atas $80 \%$ ).

12 dari 35 peserta (34\%) menyatakan sangat setuju bahwa program PkM ini sudah sesuai dengan tujuan kegiatan itu sendiri. Sisanya menyatakan setuju. 8 dari 35 (23\%) responden menyatakan sangat setuju bahwa program PkM ini sudah sesuai dengan kebutuhan masyarakat sasar.

5 dari 35 peserta (14\%) menyatakan sangat setuju waktu pelaksanaan program PkM ini relatif telah mencukupi sesuai kebutuhan. Namun ada yang mengatakan ketidaksetujuannya dengan alasan waktu pelaksanaan ini dirasa kurang terutama dalam praktek. Selanjutnya 22 dari 35 peserta (63\%) menyatakan sangat setuju bahwa Dosen dan Mahasiswa Telkom University bersikap ramah, cepat dan tangap membantu selama kegiatan. 25 dari 35 orang (72\%) menyatakan sangat setuju bahwa peserta menerima dan mengharapkan program PkM di masa yang akan datang. Berdasarkan 
feedback dan tinjauan hasil yang dicapai, maka dapat dirumuskan rencana kegiatan PkM lebih lanjut yaitu berupa upaya peningkatan daya saing produk UKM \& Koperasi Kabupaten Bandung melalui desain kemasan.

\section{DAFTAR PUSTAKA}

[1] Nancarrow, C., Wright, L.T., Brace, I. 1998. "Gaining competitive advantage from packaging and labelling in marketing communications", British Food Journal, Vol. 100 Issue: 2, pp.110-118, https://doi.org/10.1108/00070709810204101

[2] Lestari, D.A.S. 2013. Redesain Kemasan Produk Makanan Ringan "Aneka Gorengan Super 2r". Tersedia di http://lib.unnes.ac.id/19515/1/2451308011. pdf. Diakses tanggal 7 maret 2018

[3] Perhimpunan Riset Pemasaran Indonesia (PERPI). (2018). Indonesia Market Behaviour Outlook. available at http://perpi.or.id/indonesia-market-behaviour-outlook-2018-2/

[4] Simamora, Bilson. 2007. Panduan Riset dan Perilaku Konsumen. Jakarta: Gramedia.

[5] Baltazar, Mark. 2013, 28 Januari. Unlocking the secrets of persuasive packaging [website] tersedia di https://www.canadianpackaging.com/features/unlocking-thesecrets-of-persuasive-packaging/

\section{Lampiran}
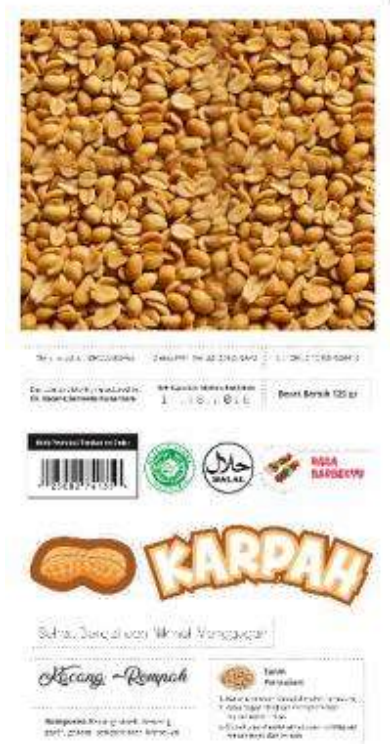

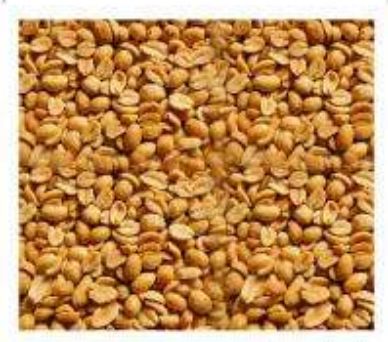

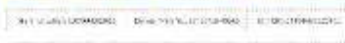
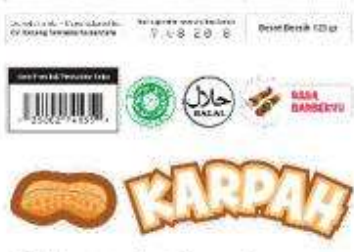

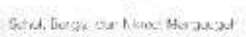

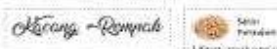

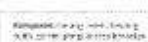

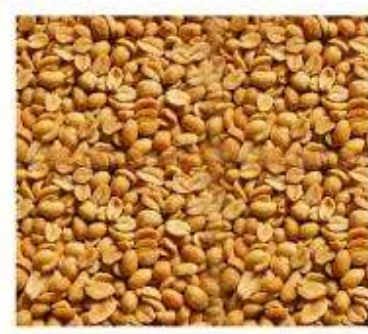

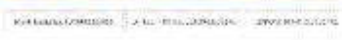

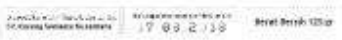
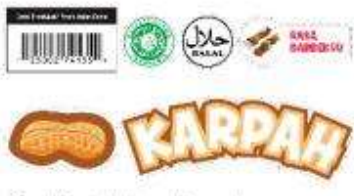

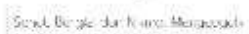

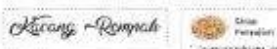

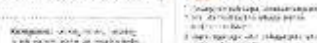



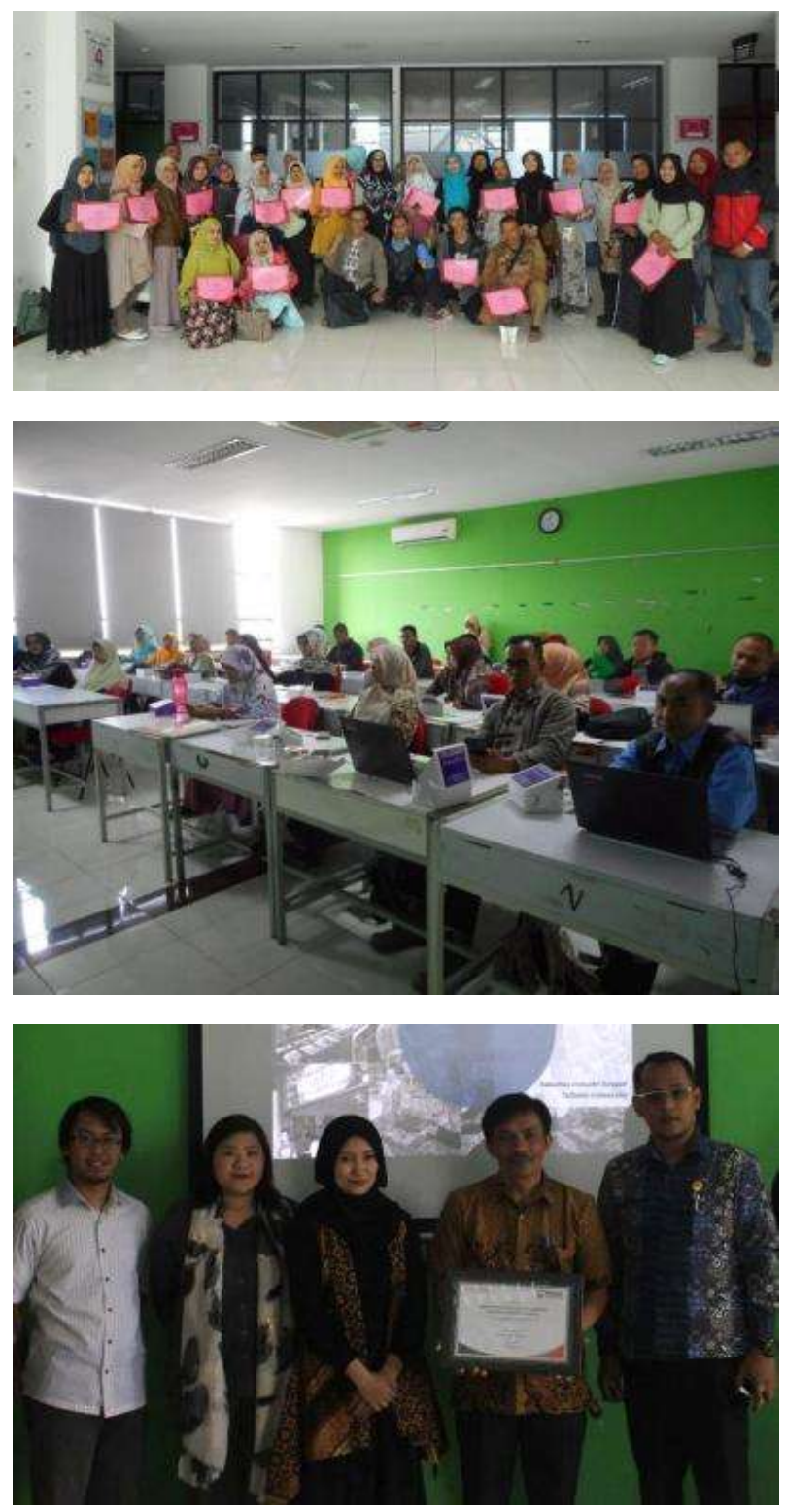

\section{Identitas Penulis}

1. Wirania Swasty, S.Ds., M.AB. adalah dosen Program Studi Desain Komunikasi Visual, Fakultas Industri Kreatif, Universitas Telkom. Area yang diminati adalah bidang desain kemasan, branding, marketing dan desain grafis lingkungan

2. Yanuar Rahman, S.Ds., M.Ds. adalah dosen Program Studi Desain Komunikasi Visual, Fakultas Industri Kreatif, Universitas Telkom. Area yang diminati adalah desain buku dan ilustrasi.

3. Atria N. Fadilla, S.Ds., M.Ds. adalah dosen Program Studi Desain Komunikasi Visual, Fakultas Industri Kreatif, Universitas Telkom. Area yang diminati adalah elemen desain grafis, tipografi dan layout, design thinking. 